\title{
do quase nada de uma noite
}

Poemas inéditos de Vera Lúcia de Oliveira Maccherani ${ }^{1}$

leves de caminho

feito pelo fundo da noite

alguns não chegam mas

pedem espaço pedem

arcabouço para sobreviver

outros se derramam

sobre bancos mudos

de jardins desesperados

alguns só habitam bordas

de desfiladeiros onde sempre

caem e se levantam sempre

caem e se levantam

\footnotetext{
1 Vera Lúcia de Oliveira Maccherani nasceu em Cândido Mota (Brasil) e reside na Itália desde 1985. É poeta, ensaísta e professora de Literatura Brasileira na Universidade de Perugia. Formou-se em Letras no Brasil e doutorou-se Itália. Escreve em português e em italiano e tem poemas publicados em vários países. Sua obra aborda temas como os processos de alteridade, deslocamentos, desterritorialização, marginalização de indivíduos. Recebeu diversos prêmios, entre os quais: Prêmio Sandro Penna (Perugia, 1988), Prêmio de Poesia da Academia Brasileira de Letras (2005), Prêmio Literatura para Todos (Brasília, 2006), Prêmio Internacional de Poesia Pasolini (Roma, 2006). Entre os livros publicados: Geografia d'ombra, 1989 (poesia); La guarigione, 2000 (poesia); Poesia, mito e história no Modernismo brasileiro, 2015 (ensaio); A chuva nos ruídos, 2004 (poesia); Verrà l'anno, 2005 (poesia); A poesia é um estado de transe, 2010 (poesia); La carne quando è sola, 2011 (poesia), Vida de boneca, 2013 (infantil); O músculo amargo do mundo, 2014 (poesia); Ditelo a mia madre, 2017 (poesia); Minha língua roça o mundo, 2018 (poesia).
} 
disse que não ia morrer

como toda gente

bastaria ir sumindo pelas brechas

da madeira velha dessa casa

que ela mesma ajudou a construir

disse que a deixassem mofar

pingar rachar esfarelar-se

onde o cimento vai sendo

puído pelo tempo e o metal

dos pregos se enferrujando

ali entraria na terra

como vira entrar todos

os mortos que por baixo

dela aguardavam

seus ossos 
$* * *$

andava por telefones

ocupava linhas

trem ali não havia

nem trilhos no chão

discava para o nada

e nenhum vagão 
$* * *$

país de palha

onde me fiz

em beirada de cama

vendo o pai morrer

levou de mim

o que nem me deu

nessa dor comida

com garfadas de feijão

com arroz

país de estopa que a mãe alvejava

e no branco aberto muitos dos

pássaros me ensinaram a voar

país de grama e terra molhada

país de arame farpado

que nos enrolou a língua

país de facas apertadas

nessa garganta limpa 
$* * *$

no silêncio que é marulho

de vaga que não espraia

vai porque o corredor convoca

porque as rachaduras da escada

respondem quando a onda bate

contra a cabeça e mareja os olhos 
despeja-se da tela o maciço do corpo forte não se vê o outro abaixo rasurado raso baixo

não se vê o porte o peso a altura a proporção não se vê o peito ali que bate bate não se vê como olha sua mãe do lado de lá desse chão gelado não se vê como nota um carrinho que passa não se vê como ouve a voz que grita moço ele não respira moço ele não não se vê se treme se pulsa nas têmporas não se vê se baba se sua chora faz xixi na calça não se vê se contrai a mão se repuxa os pés num espasmo de vida quando se vai não se vê se bate ainda o coração não se vê se morre morre morre morre não se vê ${ }^{1}$ segurança de um supermercado no Rio de Janeiro, em 14 de fevereiro de 2019, diante da mãe. 


\section{A notícia}

\section{A Meirielle}

da ponta da caneta

foi saindo o sangue

lento pingado

formando poça

no papel

gotejou na cadeira

escorreu em fio

de formigas loucas

por todas as pontas

das linhas

do jornal 